\title{
Characterising a novel mouse model with a mutated ciliopathy gene (Cep290) leading to Joubert Syndrome
}

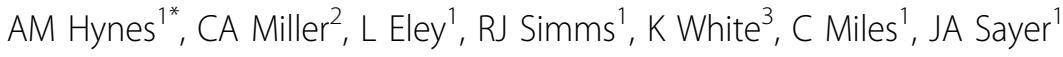 \\ From First International Cilia in Development and Disease Scientific Conference (2012) \\ London, UK. 16-18 May 2012
}

Joubert syndrome (JBTS) is an inherited ciliopathy leading to a cerebellum-retinal-renal syndrome. Recent genetic advances have allowed positional cloning and identification of numerous JBTS genes. CEP290, one of the JBTS genes identified, (alias NPHP6) encodes a centrosomal protein and accounts for $7 \%$ of patients with Joubert syndrome. We have identified a murine Embryonic Stem (ES) cell line containing a Cep290 "gene trap" using data base searches. ES cells were cultured before injecting into murine blastocysts to create chimaeric mice. Chimeras were bred to produce viable, healthy heterozygous mutant mice. Heterozygous mutant mice have been intercrossed to produce mice homozygous for the Cep290 truncating mutation. Cep290-/- animals (homozygous for the gene trap Cep290) exhibit a cortico-medullary cystic kidney disease commencing from birth. Histological examination reveals that these cysts are collecting duct in origin, staining positively for aquaporin- 2 and -3 . In this study the cilia were investigated in cystic Cep290-/- animals using Electron Microscopy (EM) analysis. Scanning electron microscopy (SEM) identified that cilia were evident within renal tubules in Cep290-/- animals. Once cilia were identified in Cep290-/- animals Transmission Electron Microscopy (TEM) was carried out to investigate cross sections of the collecting duct cilium in cystic and non-cystic kidneys. TEM analysis identified tubular basement membrane disruptions in Cep290-/- animals. The Cep290-/- mouse described provides an excellent model to investigate the mechanisms involved in cyst formation and to test novel therapeutic agents.

\footnotetext{
* Correspondence: ann.hynes@ncl.ac.uk

${ }^{1}$ Institute of Genetic Medicine,Newcastle University, International Centre for Life, UK

Full list of author information is available at the end of the article
}

\section{Author details}

${ }^{1}$ Institute of Genetic Medicine,Newcastle University, International Centre for Life, UK. ²Electron Microscopy Core for PKD Research, Department of Anatomy \& Cell Biology, Indianapolis University School of Medicine, USA. ${ }^{3}$ Electron Microscopy Research Services, Catherine Cookson Building, Newcastle University Medical School, UK.

Published: 16 November 2012

doi:10.1186/2046-2530-1-S1-P89

Cite this article as: Hynes et al:: Characterising a novel mouse model with a mutated ciliopathy gene (Cep290) leading to Joubert Syndrome. Cilia 2012 1(Suppl 1):P89.

\section{Submit your next manuscript to BioMed Central and take full advantage of: \\ - Convenient online submission \\ - Thorough peer review \\ - No space constraints or color figure charges \\ - Immediate publication on acceptance \\ - Inclusion in PubMed, CAS, Scopus and Google Scholar \\ - Research which is freely available for redistribution

